\title{
Pathological manifestations from the presence of moisture in buildings: Maintenance proposal
}

\author{
Rita de Cássia Teixeira Assis ${ }^{1 *}$; Julie Catherine Siqueira Santana ${ }^{2}$; Kariny Ferreira Moreira ${ }^{2}$; \\ Richard de Paula Silva ${ }^{2}$ \\ *Contact author: rita.assis@engenharia.ufjf.br \\ ${ }^{1}$ Civil Engineer, Teacher at Faculdade Vértix Trirriense, Master's student in Built Environment at the Federal \\ University of Juiz Fora, Juiz de Fora, Brazil. \\ ${ }^{2}$ Graduating in Civil Engineering from Faculdade Vértix Trirriense, Três Rios, Brazil.
}

\begin{abstract}
In view of the lack of attention given to maintenance activities, this article aims to analyze the pathological manifestations arising from the presence of moisture in buildings, as well as presenting maintenance procedures that can be adopted, to minimize the anomalies presented in housing developments. For this, a literature review was carried out, associated with a case study in the city of Três Rios / RJ, which through a photographic report, allowed to map the most frequent occurrences, especially in concrete structures, sealing masonry, and coatings. The results showed that most of the pathological manifestations identified are due to the lack of an adequate waterproofing design or poor maintenance. Proper planning of maintenance activities is essential to ensure the durability and fulfillment of the building's useful life. It is expected, with this study, to highlight the importance of projects, technical monitoring during the execution of works, and even regular inspections, which is fundamental for the safety and quality of life of users.
\end{abstract}

Key words: Pathology, Building maintenance, Moisture

\section{RESUMO}

Tendo em vista a falta de atenção dada às atividades de manutenção, esse artigo tem como objetivo analisar as manifestações patológicas provenientes da presença de umidade em edificações, bem como apresentar procedimentos de manutenção que podem ser adotados, para minimizar as anomalias apresentadas nos empreendimentos habitacionais. Para isso, uma revisão de literatura foi realizada, associada a um estudo de caso na cidade de Três Rios/RJ, que através de um relatório fotográfico, permitiu mapear as ocorrências mais frequentes, especialmente em estruturas de concreto, alvenaria de vedação e revestimentos. Os resultados mostraram que a maioria das manifestações patológicas identificadas são oriundas da falta de um projeto adequado de impermeabilização ou manutenções deficientes. O planejamento adequado das atividades de manutenção é essencial para garantir a durabilidade e o cumprimento da vida útil das edificações. Espera-se, com esse estudo, destacar a importância dos projetos, do acompanhamento técnico 
durante a execução de obras e ainda das inspeções regulares, fundamental para a segurança e qualidade de vida dos usuários.

Palavras-chave: Patologia; Manutenção predial; Umidade.

\section{RESUMEN}

Ante la falta de atención a las actividades de mantenimiento, este artículo tiene como objetivo analizar las manifestaciones patológicas derivadas de la presencia de humedad en las edificaciones, así como presentar los procedimientos de mantenimiento que se pueden adoptar, para minimizar las anomalías que se presentan en los desarrollos habitacionales. Para ello, se realizó una revisión de la literatura, asociada a un estudio de caso en la ciudad de Três Rios / RJ, que, a través de un reportaje fotográfico, permitió mapear las ocurrencias más frecuentes, especialmente en estructuras de hormigón, mampostería de sellado y revestimientos. Los resultados mostraron que la mayoría de las manifestaciones patológicas identificadas se deben a la falta de un diseño de impermeabilización adecuado o al mal mantenimiento. Una adecuada planificación de las actividades de mantenimiento es fundamental para garantizar la durabilidad y el cumplimiento de la vida útil del edificio. Se espera, con este estudio, resaltar la importancia de los proyectos, el seguimiento técnico durante la ejecución de las obras e incluso las inspecciones periódicas, lo cual es fundamental para la seguridad y calidad de vida de los usuarios.

Palabras clave: Patología, Mantenimiento del edificio, Humedad

\section{INTRODUCTION}

The action of water has a significant effect, often negative, when analyzing the durability of buildings, as it can cause damage or trigger many of the existing traditional pathological manifestations (ROCHA et al., 2018).

The study of constructive failures, defined as the pathology of constructions, is an experimental science of a multidisciplinary character, not limited to cases of quality problems of the materials used or the quality of construction performance, but they are also consequences of deficiency or absence of documentation involved, such as design flaws and omissions in engineering projects, descriptive memorials, and user manuals (SANTOS e PENTEADO NETO, 2020).

Tales studies, Oliveira and Ruppenthal (2017) They emphasize that investments in the construction phase of a building are essential so that in the future the costs in maintenance and habitability are lower.

Throughout the useful life of buildings, it is expected that they will suffer some type of degradation. According to Danco, Haddad, and Evangelista (2016), through the use of good quality materials during the work, it is possible to avoid losses of materials due to defects, avoid repairs and early maintenance. With this, in addition to increasing the useful life, the environmental impacts generated are reduced, since it is not necessary to produce new materials for their replacement. Although there are several benefits from preventive maintenance, according to Amorim et al. (2013), corrective maintenance still prevails, occurring due to absence or deficiency in the schedules of other maintenance and generating higher functional and financial costs. In addition, to ensure the efficiency of maintenance, it is important to have teams with qualified professionals 
to carry out these activities. A possible and efficient solution for this is to deliver these tasks to third-party companies specialized in the subject.

Thus, this work seeks to investigate the pathological manifestations resulting from the presence of humidity, in residential buildings analyzed in the city of Três Rios / RJ. Specific objectives include: (a) Mapping recurrent anomalies; (b) Identify the design and/or execution deficiencies that caused such pathological manifestations, and (c) Suggest maintenance alternatives solve the problems raised.

It is intended, with this research, to contribute to the quality of housing buildings, in addition to highlighting the importance of carrying out maintenance activities for the conservation of buildings and their systems.

\section{THEORETICAL FOUNDATION}

\subsection{The origin of the studies of pathology}

According to Vieira (2016), the anticipated set of deterioration in which a building is exposed causes different damages to buildings. Caused by several reasons, such as natural aging, irresponsibility, and occupational accidents that use questionable materials, among others. With this previous deterioration of buildings, the need arose to create a new field within engineering building pathology, in order to study this problem scientifically, portraying its behavior, its origins, its symptoms, and its causative agents.

Pathological problems are common within the life of a civil engineer, especially those related to humidity. Moisture in buildings is one of the most difficult aspects to be resolved or treated within civil construction. Not only because of the complexity of the phenomena but also because of all the construction flaws, such as waterproofing. It is common for this problem to be associated with others, which makes treatment even more difficult. The presence of any type of moisture described above can cause various pathological manifestations in the structures.

\subsection{Pathological manifestations and their consequences}

The episode of pathological problems in buildings causes a reduction in their useful life, which is directly linked to the performance of the materials and components present in the building. Pathological problems exhibit external manifestations with certain peculiarities, and through this characteristic, it is possible to deduce which origin, nature, and mechanisms of the phenomena involved, in the same way, that its possible consequences can be estimated. Problems such as those mentioned are of an evolutionary nature, that is, they tend to worsen over time. (HELENE, 1992). According to the text by Souza and Rieper (1998), the difficulty in recovering from failures even in the initial period of the work makes the work considerably more expensive. Thus, when taking costs into account, the greater the evolution of the work, the closer to the end the greater the costs of repairing and recovering from failures. With this, Helene (1992) also states that: "the corrections will be more durable, more effective, easier to perform and much cheaper the sooner they are performed".

In general, pathological problems are of an evolutionary nature and tend to increase their degree of complexity, which may end up causing other problems arising from the initial situation. With

that, it can be said that the corrections will be more durable, easy to execute, and cheaper the sooner they are executed. This thinking has as its segment the "Law of Sitter", which 


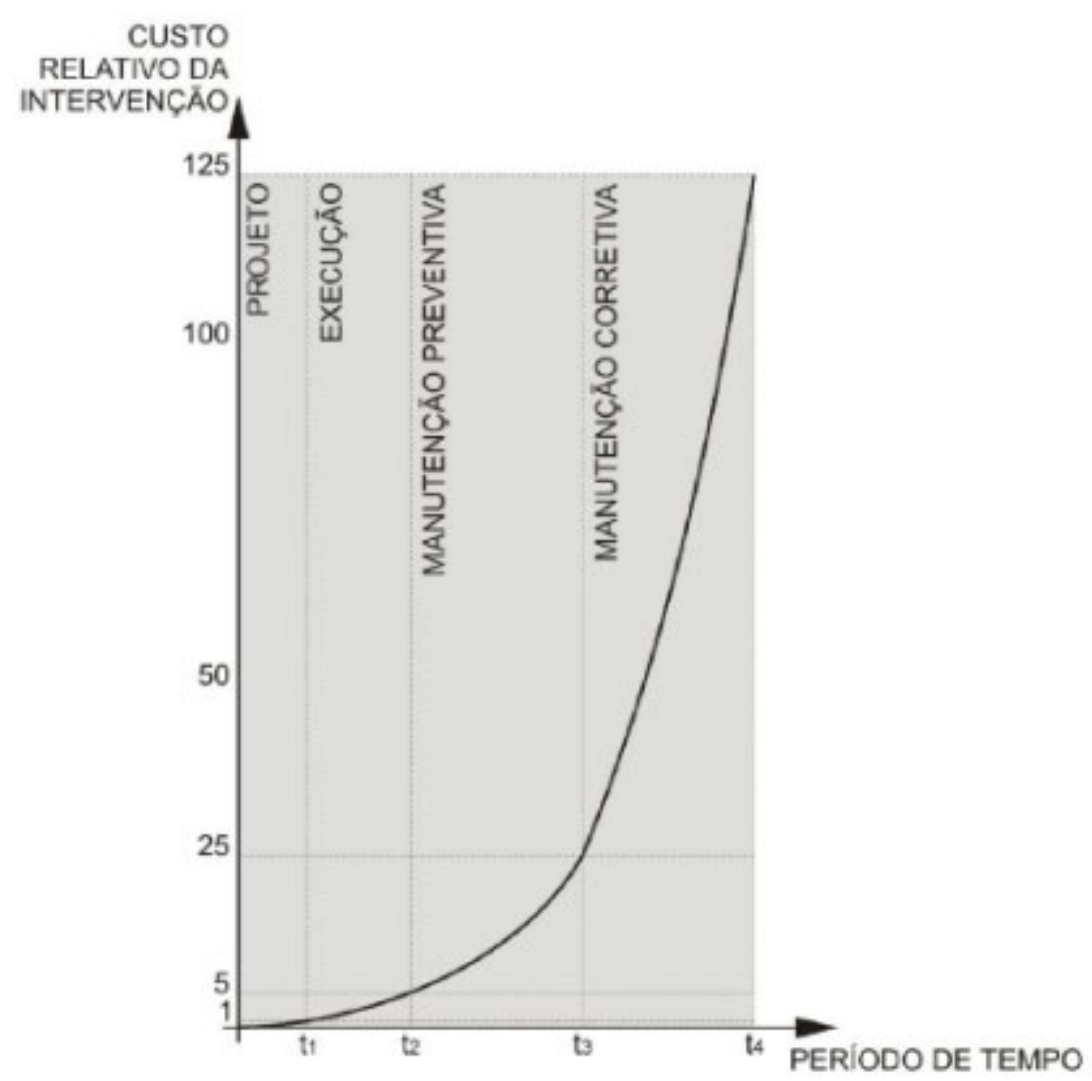

Figure 1- Cost evolution law (Sitter,1984)

Source: CEB RILEM (adapted Helene, 2003, p. 27)

Figure 1 shows through the graph that there is an exponential increase in cost in relation to the solution time. When observing the axes and phases of the work, it is clear what HACKBARTH (2006) states, that the later the correction is made, the higher the cost. Thus, demonstrating the importance of perceiving problems at the project stage.

However, the problems are not only limited to costs, these defects generate serious problems and complicated solutions. Examples of this situation: Damage to the building's functional character, users' discomfort, and in extreme cases they can affect the health of residents with respiratory diseases. Damage to property that is present inside buildings.

Following Verçosa's (1991) thought, humidity is not only a cause of pathology, it acts as a trigger for other pathologies to occur in buildings. It is a prime fuse for the appearance of rust, mold, mold, efflorescence, mold, loss of plaster, damage to the finish, as in painting, and even the cause of structural accidents.

According to Macedo (2017), the lack of maintenance or inadequate maintenance, causes the appearance of pathologies, causing undesirable performance, high recovery costs, and can generate risk to the lives of the in habitants.

\subsection{The maintenance of situation as a form of prevention}

The quality of human life suffers a great influence when related to the built space where it is inserted. Thus, it is important that all buildings have conditions suitable for the use for which it is 
intended, resisting the use and the weather itself. However, maintenance activities are still seen as a financial problem and do not have a priority when it comes to execution, while the correct thing would be to adapt it as a type of investment since it is possible to delay aging and add value to the final product (CREA-DF, 2014).

Building maintenance goes beyond aesthetics. Social, economic, legal, environmental, and technical issues are variables involved in the process itself. In first-world countries, keeping the built space in good condition is a cultural issue. Building inspection services, for example, are carried out naturally, which clearly shows the consolidation and importance of this activity in countries (NEVES e BRANCO,2009).

With all this, innumerable questions are asked in Brazil and put, in theory, our culture regarding building maintenance. Many studies claim that we are still a long way from the reality of the "first world" and that there is a huge gap when it comes to preventive maintenance.

The practice of Brazilian Maintenance, currently, is focused on repairing what is broken, without the availability of resources necessary for the implementation of a specific activity plan for each enterprise, which should consider some fundamental points for the success of the maintenance program, which are: elapsed life of the facilities, types, and frequencies of use, hours of operation of machines and equipment, 14 operational and performance losses (PUJADAS, 2006).

Thus, the importance of maintenance for the different types of assets is undeniable. It is not feasible to maintain a building without maintenance interventions for a fixed period. The guarantee of longer useful life and with a considerable level of satisfaction can only be dealt with mainly taking into account functional and structural performance if it is subjected to adequate maintenance, which is done with efficient management.

Thus, it is the responsibility of the Brazilian standards to define the concept of Maintainability as: Maintainability is the degree of ease of a system, element, or component to be maintained or returned to the state in which it can perform its required functions, under specified conditions of use, when maintenance is performed under specified conditions, procedures and prescribed means (NBR 15575/2013).

The ABNT NBR 5.674/2012 divides maintenance actions into three types: routine, preventive and corrective.

Routine maintenance: Characterized by a constant flow of services, standardized and cyclical, which can be scheduled daily, weekly, or even monthly, without affecting the users' routine. It is usually related to the conservation of the building, for which only equipment and permanent staff are needed.

Preventive maintenance: It includes services whose realization is scheduled in advance, according to the specific periodicity for each system, in order to minimize its chances of failure or degradation. It is essential, for the success of preventive maintenance, that specifications about the facilities and equipment existing in the building are available.

Corrective maintenance: Defined by services that require immediate action or intervention to allow the continued use of building systems, elements, and components, or to avoid serious risks and personal or property damage to its users. Usually, maintenance activities require the greatest technical and administrative efforts, as they are more complex.

Therefore, according to what has been exposed, it is necessary to have a broad view on the concept, definition, and execution of maintenance, the break of paradigm where that maintenance is an item that is only considered in the post-occupation or after the appearance of the consequences of not maintaining it in a technical way. It is vital that maintenance is still considered in the design phase, 
as these are the steps that make it possible to change and evaluate which maintenance, reducing the need for maintenance in the post-work and reducing costs.

\section{METHODOLOGY}

To make it possible to add value to work and contribute to society, we first sought to contextualize work with problems that bother users from different homes. It was necessary to characterize the problem and bring real examples to it, in order to provide an applied basis with real day-to-day situations, so that later a solution could be created based on the degree of pathology, safety, and costs.

The present study is a study applied to the bibliographic review procedure, where articles researched on the platforms were used: Periodicals Capes, Scielo, and other bases referenced in this study. The Bibliographic Review is part of a research project, which explicitly reveals the universe of scientific contributions by authors on a specific topic (SANTOS e CANDELORO, 2006, p. 43).

For the elaboration of the review, existing bibliographies on the subject in question and studies related to the areas covered were used. Taking into account the studies found systems and mechanisms that aim to solve the pathologies that were found in the case studies were scored.

Theoretical references were also adopted, the Technical Norms referring to the theme, graduation work, graduate and master's theses. The use of presentations at congresses and finally, technical information materials from the civil construction area such as CREA. Through the bibliographic review, information can be obtained about the humidity in the buildings and what changes they can make to the building elements and the materials that constitute them.

As the second stage of this research, a case study was carried out in the city of Três Rios (RJ), where several homes with pathological problems due to humidity were analyzed, with the objective of carrying out an assessment and pointing out solutions for such cases. The study information was collected from interviews and technical visits with the monitoring of an engineering company in the city of Três Rios. With the separate information, with the photographs were taken on the spot, an action plan for the maintenance of the aforementioned locations was drawn up, with proposals for improvements, using the bibliographic review to which we had access as a basis.

During the inspection, we sought to identify only the pathological manifestations caused by moisture, especially in concrete structures, sealing masonry, and coatings.

\section{RESULTS AND ANALYSIS}

\subsection{Pathologies in Concrete Structures}

As the object of analysis and study, a structure was selected where the infiltration of the structure and the corrosion of the reinforcement were found, as shown in the figure below: 


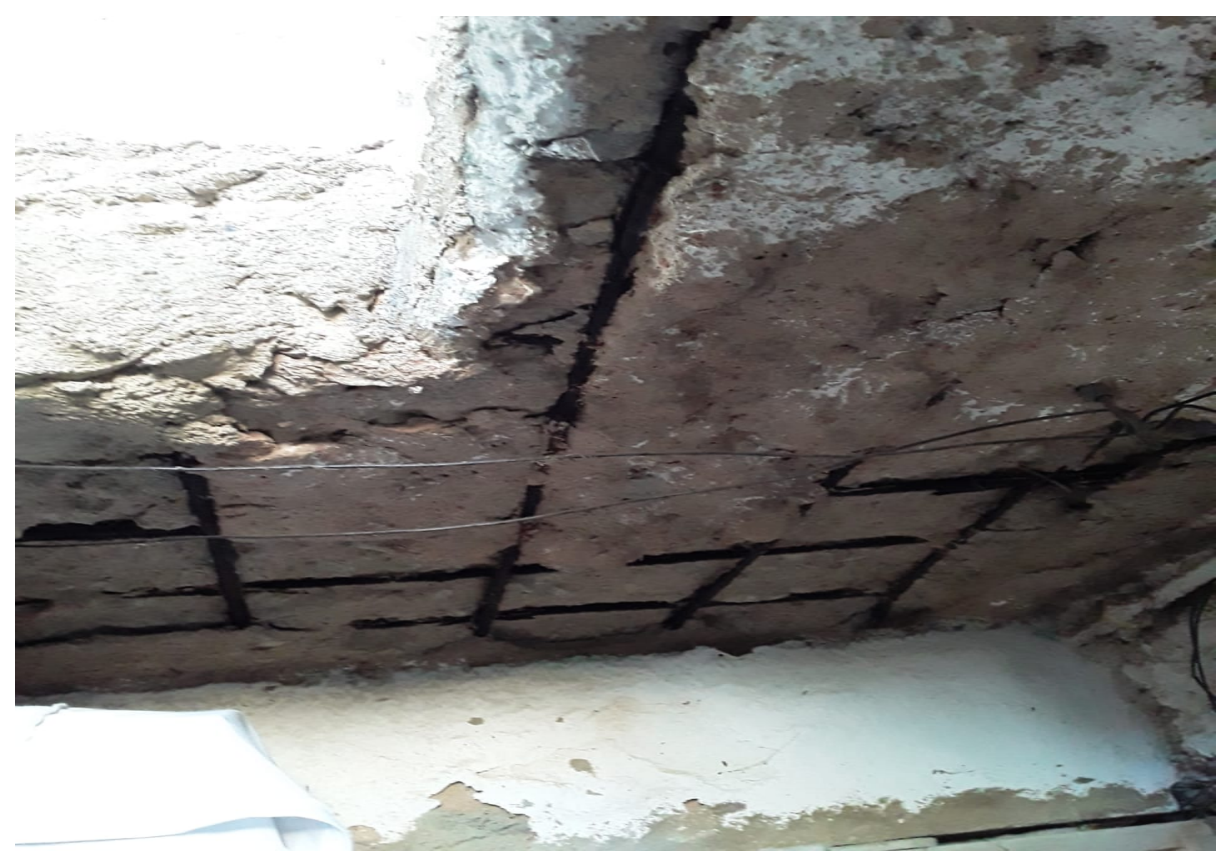

Figure 2: Structure with infiltration and corrosion of armature Source: Authors' Collection (2021).

The average relative humidity of the city of Três Rios is normally above 70\% (CLIMATE, 2021), making the environment more conducive to the carbonation of concrete and facilitating electrochemical corrosion in the reinforcement, coupled with low rainfall in the city, which increases the residence time of the electrolyte film in the structures (ALBUQUERQUE AND OTOCH, 2005), it becomes consistent that the corrosion of armatures was the most prevalent pathological manifestation in the city's buildings.

Carbonation is one of the main physical-chemical phenomena that can limit the useful life of reinforced concrete structures. By reducing the alkalinity of the concrete, it changes the chemical stability conditions of the passive reinforcement film, creating favorable conditions for the start of the corrosive process. This reduction results from the reactions between the carbon dioxide (CO2) 48 of the atmosphere and the cement hydration products, in the presence of moisture. As a result, there is a reduction in the $\mathrm{pH}$ of the concrete, originally greater than 12.5 , to values around 8.5 (BAKKER, 1988, MEHTA and MONTEIRO, (2008).

Infiltration, according to Nince (1996), is mainly associated with design problems (architectural design and installations) and the lack or deficiency of maintenance.

\subsection{Pathologies in sealing masonry}

According to Godoy (2019), the changes generated in the construction process end up generating a greater number of construction failures and overload of the structures. The increasing demand for fast delivery means that the shoring is not used in its minimum necessary time and the wedging does not receive due attention. What generates tensions and deformations above the allowed, causing cracks and cracks in the coatings. In sealing masonry, the function of the treatment is to prevent the entry of agents that potentiate the pathological manifestations in the environment, humidity, and the aesthetic part that generates great discomfort. 


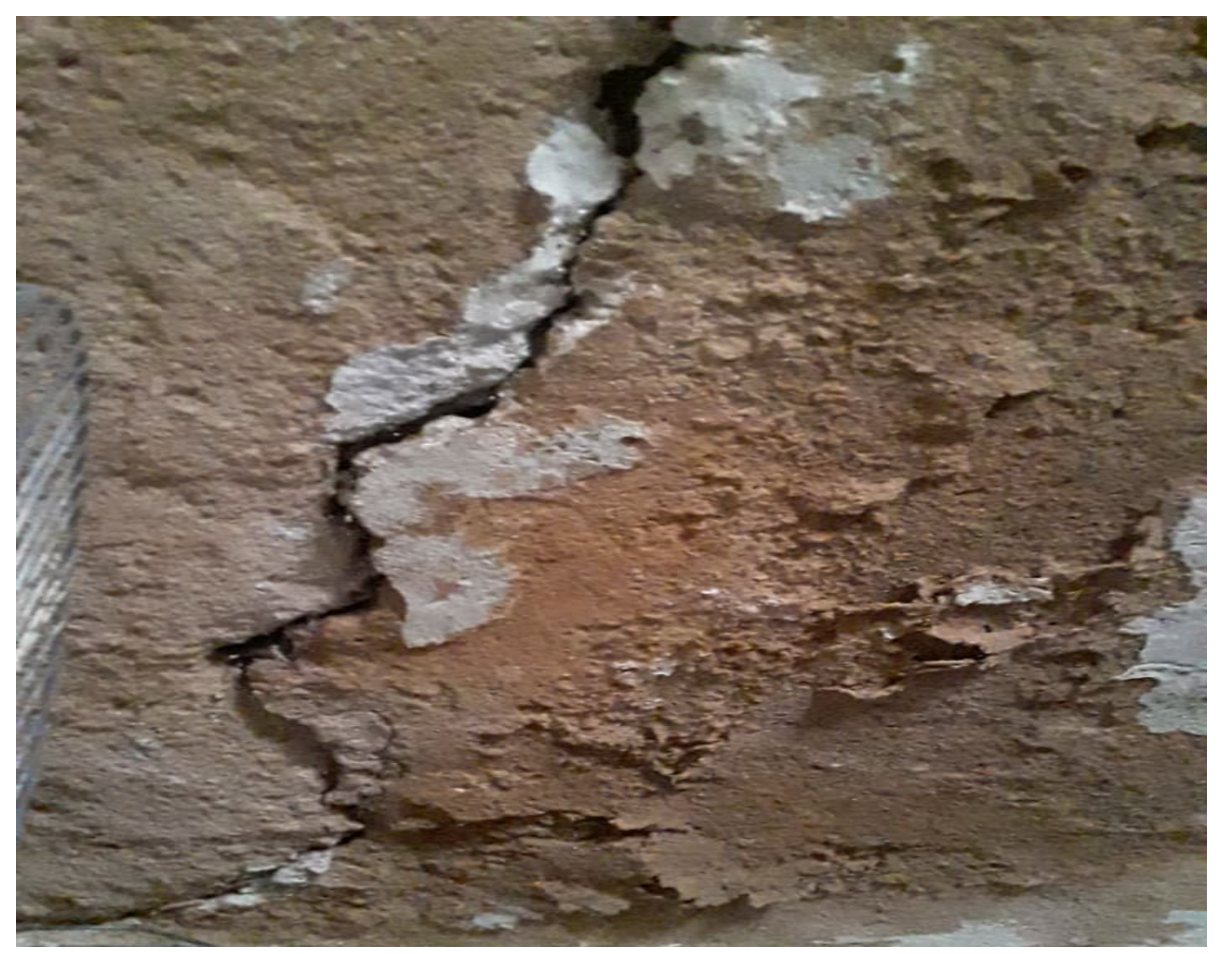

Figure 3: Crack in sealing masonry

Source: Collection of authors (2021).

Cracks can occur in different ways, motives, and phases of a building, as listed by engineer Paulo Grandiski, from Ibape-SP (Brazilian Institute of Engineering Assessments and Expertise of São Paulo):

In a simplified overview, the origins of the cracks in a building can arise in the phase of architectural, structural, foundation, installations, masonry execution, the various finishing systems, and, even, in the use phase, for example. Misuse of the unit.

\subsection{Pathologies in coatings}

According to Jonov, Nascimento, Paula, and Silva (2013), humidity and infiltration, protagonists in these types of pathology, represent a problem that is difficult to solve and very frequent in buildings. Factors such as the age of the building, climate, materials, construction practices used, and the degree of quality control during its execution influence how much this type of anomaly occurs. Moisture can manifest itself in several ways, such as stains, mold or mildew, cracks, among others, as shown in the case below: 


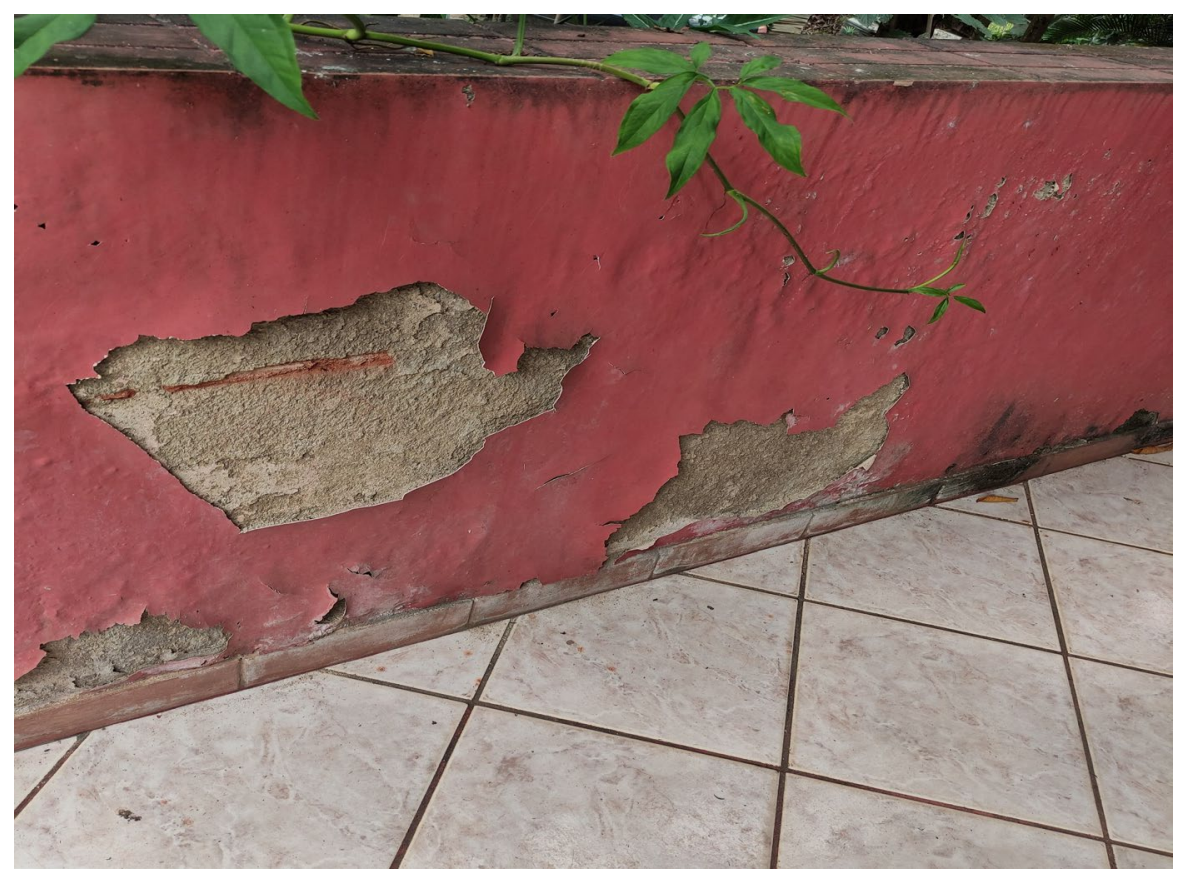

Figure 4: Coated wall showing moisture and seepage.

Source: Collection of authors (2021).

\subsection{Maintenance proposals}

As regulated by ABNT NBR 5,674 / 2012, the management of the maintenance program must consider the main characteristics of the building such as the typology, the use, its extension, among others. This maintenance is guided by guidelines that have as one of its focuses to ensure the performance expected in the project over time, mainly in order to avoid depreciation of the building.

The maintenance program mainly determines what activities will be performed, documentation, labor, among others. For the cases mentioned above, maintenance proposals based on this program will be presented below.

\subsubsection{Concrete Structures}

A process to be carried out before maintenance, according to Da Silva (2006), is the preparation and cleaning of the surface to be treated. The procedures to be performed according to the problem are:

- Polish;

- Washing and cleaning the surface;

- Removal of residues with the use of acidic or alkaline solutions;

- Removal of waste using water, steam, sand or compressed air;

- Manual brushing;

- Chipping;

- Saturation;

- Concrete Cutting. 
Prepared the surface and with the reinforcement cleaned or replaced if necessary, the recovered area must be recomposed using the materials found on the market, such as:

- Mortar;

- Grout;

- Concrete.

\subsubsection{Sealing masonry}

As in the case of concrete structures, the sealing masonry must undergo cleaning and preparation of the surface, after this step the maintenance of the masonry stands out, as the materials listed below:

- Waterproof liquid blanket;

- Geotextile VP 40;

- Polyester fabric;

- Fiberglass screen.

\subsubsection{Coatings}

For the maintenance of coatings, you must first find out the source of the problem as it can have several sources, the main ones being:

- Slabs with poor waterproofing;

- Infiltration from rain;

- Infiltration from bucket beams and shallow foundations;

- Pipe leakage.

Once the source of the problem has been found, it is recommended to remove the infiltrated and non-infiltrated material up to $30 \mathrm{~cm}$ in height from the infiltration line verified on the wall, and then apply the most suitable waterproofing material for the surface to be recovered, be it:

- Ceramics;

- Porcelain;

- Cement;

- Wood;

- Stone;

- Tiles.

\section{CONCLUSIONS}

The implementation of the maintenance program is an extremely effective tool in reducing anomalies and pathological failures. Problems related to pathological action are present in all phases of the life of a building, it is up to the technician to conclude which prevention is the best solution for the case. Correcting errors even during the project is paramount.

Of the failures and anomalies found during the inspections carried out, about $85 \%$ are caused by the lack of an adequate waterproofing project or originated from maintenance carried out in an erroneous manner. The implementation of a waterproofing system or technical monitoring in the design stage prevents expenses and above all manages to adapt the type of maintenance of the problems presented. It is also notorious, the connection between the failures and anomalies 
presented. The degree of anomalies varies between critical and regular, where maintenance can be adequate in long and medium-term interventions.

A complete maintenance plan is recommended due to the degree of risk of anomalies and failures found. The detection of these anomalies brings with it the importance of regular inspections, which are essential for the safety and quality of life of users. With the inspection carried out, we can present a maintenance proposal, facilitating a therapy and maintenance plan.

It is necessary to have a debate between technicians and users to prepare an inspection schedule and an owner's manual, a document that contains guidelines about the care that must be taken with the affected building, following technical priorities, and application of resources that aim to improve safety. And the quality of life for residents or end-users.

\section{REFERENCE S}

ABNT ASSOCIAÇÃO BRASILEIRA DE NORMAS TÉCNICAS. NBR 5.674: Manutenção de Edificações - Requisitos para o sistema de gestão de manutenção. Rio de Janeiro, 2012.

ABNT ASSOCIAÇÃO BRASILEIRA DE NORMAS TÉCNICAS. NBR 15575 - Edificações habitacionais - Desempenho. Rio de Janeiro, 2013.

ALBUQUERQUE, A. T. OTOCH, S. Proposta de classificação da agressividade do ambiente na cidade de Fortaleza. In: CONGRESSO BRASILEIRO DO CONCRETO, 47., 2005, Olinda. Anais... Olinda: IBRACON, 2005. p. 743-748.

AMORIM, G. M.; QUINTÃO, E. C. V.; MARTELlI JUNIOR, H.; BONAN, P. R. F. Prestação de serviços de manutenção predial em Estabelecimentos Assistenciais de Saúde. Ciência coletiva [online]. 2013, vol.18, n.1, pp.145-158. doi: https://doi.org/10.1590/S1413-81232013000100016.

BAKKER, R. F. M. Initiation period.In: Schiessl, P., ed. Corrosion of steel in concrete. London, Chapman and Hall, 1988, cap. 3, p.22- 55.

CLIMATE. Temperatura, tempo e dados climatológicos. Disponível em: https://pt.climatedata.org/america-do-sul/brasil/rio-de-janeiro/tres-rios-33689/. Acesso em 13/05/2021

Conselho Regional de Engenharia e Agronomia (Crea-DF). Cartilhas dos síndicos: obras e serviços de Engenharia e Agronomia: o que é preciso saber. 2014.

CONTO, V.; OLIVEIRA, M. L.; RUPPENTHAL, J. E. Certificações ambientais: contribuição à sustentabilidade na construção civil no Brasil. Revista Gestão da Produção, Operações e Sistemas, [S.1.], v. 12, n. 4, p. 100, nov. 2017. DOI: 10.15675/gepros.v12i4.1749.

DINAMARCO, C. P. G.; HADDAD, A.; EVANGELISTA, A. Selo Casa Azul Certificação ambiental estudo de caso: Condomínio Neo Niterói. Revista Sustinere, [S.1.], v. 4, n. 1, p. 82 - 104, jul. 2016. ISSN 2359-0424. doi: http://dx.doi.org/10.12957/10.12957/sustinere.2016.24632.

GODOY, A. C. B. S. Tratamento de fissuras em alvenaria de vedação: áreas internas. Instituto CEUB de pesquisa e desenvolvimento - ICPD. Brasília, 2019 
INSTITUTO BRASILEIRO DE AVALIAÇÕES E PERÍCIAS DE ENGENHARIA DE SÃO PAULO - IBAPE. Norma de vistoria de vizinhança. Procedimentos básicos executivos. São Paulo, 2013.

HACKBARTH, F. B. Avaliação de problemas estruturais de uma edificação em concreto armado in loco com propostas de soluções. Florianópolis: UDESC, 2006.

HELENE, P. R. L. Manual para reparo, reforço e proteção de estruturas de concreto. 2. ed. São Paulo: PINI, 1992.

JONOV, C. M. P. NASCIMENTO, N. DE O. PAULA E SILVA, A. Ambiente Construído, Porto Alegre, v.1 3, n.1, p. 75 - 94, jan./mar. 2013.

MACEDO, E. A. V. B. Patologias em obras recentes de construção civil: análise crítica das causas e consequências. Rio de Janeiro: UFRJ/ ESCOLA POLITÉCNICA, 2017.

MEHTA, P. K.; MONTEIRO, P.J.M. Concreto: microestrutura, propriedades e materiais. São Paulo: IBRACON, 2008, 674p.

NEVES, D. R. R., BRANCO, L. A. M. N. Estratégia de Inspeção Predial. Belo Horizonte: Construindo, v.1, n.2, p. 12-19, jul./dez. 2009.

NINCE, A.A. Levantamento de dados sobre causas de deterioração de estruturas na região Centro-Oeste. Dissertação (Mestrado). Universidade de Brasília, Brasília, 1996.

PUJADAS, F. Z. A. XIV COBREAP, “INSPEÇÃO PREDIAL - Ferramenta de Avaliação da Manutenção”, 2007.

ROCHA, J. H. A. et al . Detecção de infiltração em áreas internas de edificações com termografia infravermelha: estudo de caso. Ambiente constr., Porto Alegre, v. 18, n. 4, p. 329-340, Out. 2018. doi: https://doi.org/10.1590/s1678-86212018000400308.

SANTOS, C. E. R. PENTEADO NETO, R. de A. Análise de frequência de vícios construtivos em habitações de interesse social: Região de Curitiba, PR. PARC Pesquisa em Arquitetura e Construção, Campinas, SP, v. 11, p. e 020025, 2020. doi: 10.20396/parc.v11i0.8656047.

SANTOS, V. D.; CANDELORO, R. J. Trabalhos Acadêmicos: Uma orientação para a pesquisa e normas técnicas. Porto Alegre/RS: AGE Ltda, 2006. 149 p. Acesso em: 11 de maio de 2021

SITTER, W. R. Costs for service life optimization. The Law of fives. In: International CEBRILEM workshop on durability of concrete structures. Procedings... Copenhagen: CEBRILEM, 1984, p. 18-20.

SOUZA, V. C. M. e RIPPER, T. Patologia, recuperação e reforço de estruturas de concreto. São Paulo: PINI, 1998.

VERÇOZA, E. J. Patologia das Edificações. Porto Alegre, Editora Sagra, 1991. 172p. 
VIEIRA, M. A. Patologias Construtivas: Conceito, Origens e Método de Tratamento. Revista Especialize On-line IPOG - Goiânia - 12a Edição nº 012 Vol.01/2016 Dezembro/2016. 